\title{
The Continuing Saga of \\ Emergency Room Overcrowding: Are We Aiming at the Right Target?
}

\section{L'interminable saga de l'engorgement des salles d'urgences : vise-t-on la bonne cible?}

\author{
by DANiÈle ROBERGe, PHD \\ Researcher, Research Centre of Charles Lemoyne Hospital \\ Associate Professor, Department of Community Health Sciences \\ Faculty of Medicine and Health Sciences, University of Sherbrooke \\ Longueuil, QC
}

RAYNALD PINEAULT, MD, PHD

Physician-Adviser, Montreal Public Health Department and Institut national de santé publique du Québec

Professor Emeritus, Faculty of Medicine, University of Montreal Montreal, QC

DANIELLE LAROUCHE, MSC

Project Coordinator, Montreal Public Health Department

Montreal, QC

LÉO-ROCK POIRIER, MSC

Research Associate, Health and Social Services, Institut national de santé publique du Québec Department of Health Systems and Public Policy

Montreal, QC 


\begin{abstract}
Emergency room utilization in Canada is considerably higher than in other industrialized countries. Despite significant investments, recurrent emergency room crises persist. Focusing particularly on the situation in Quebec, this paper examines the evolution of Canada's and Quebec's healthcare systems over the past 40 years and identifies the key developments that resulted in today's problems and the challenges that must be addressed. In this historical overview, we argue that emergency room problems arise from past decisions that gave hospitals a predominant role in the healthcare system and partly modified their original mission, as well as from counterproductive funding modalities. Other decisions have also weakened primary care services, which are strongly focused on acute health problems and are poorly coordinated with the rest of the system. Symptomatic remedies have only eased the pressure on emergency rooms, but the real solution is more complex and must address the historical residues that are paralyzing our healthcare system.
\end{abstract}

\title{
Résumé
}

Lutilisation des salles d'urgences au Canada est considérablement plus élevée que dans les autres pays industrialisés. Malgré d'importants investissements, les crises récurrentes dans les salles d'urgence continuent d'avoir lieu. Mettant l'accent sur la situation au Québec, cet article examine l'évolution des systèmes de santé québécois et canadien au cours des 40 dernières années et dégage les principaux éléments qui ont mené aux problèmes actuels ainsi que les défis auxquels il faudrait sattaquer. Dans cet aperçu historique, nous alléguons que les problèmes liés aux salles d'urgences proviennent de décisions antérieures, lesquelles ont donné aux hôpitaux un rôle prédominant dans le système de santé et ont partiellement modifié leur mission initiale. Les problèmes viennent également de modes de paiement contre performants. D'autres décisions ont également affaibli les services de soins de santé primaires, lesquels sont fortement centrés sur la réponse aux protolèmes de santé aigus et restent peu coordonnés avec le reste du système de santé. Les sparadraps auxquels on a eu recours nont fait que soulager la pression sur les salles d'urgence. Le traitement indique est plus complexe et doit sattaquer aux achaïsmes qui paralysent le système de santé.

mong industrialized countries, Canada has the highest Rate
of emergency room (ER) utilization, both in the population at large and
among persons with chronic conditions (Schoen et al. 2004, 2005, 2008). It is also Canadians who, in the highest proportions, report using the ER for services that could be provided by their regular doctor, and waiting the longest in emergency 
rooms before being seen by a physician (Schoen et al. 2004, 2005, 2008). There is very little systematic information on ER utilization in Canada, and interprovincial comparisons are constrained by differences in the types of data collected (Rowe et al. 2006). Nevertheless, for the past several years, emergency room overcrowding has been seen as a frequent and significant problem in many provinces (Rowe et al. 2006; "Emergency Ward on Lawn Approved" 1987; "ER Crowding Getting Worse" 1999; "ER Overcrowding Delays" 2004). There have been reports of ambulances being turned away, patients on stretchers in corridors and occupation rates exceeding capacity. In Quebec, since the 1970s, studies have shown an increase in ER utilization and have reported the emergence of problems with overcrowding (MASQ 1974; CSSSMM 1977; Steinmetz and Hoey 1978). Temporal analyses show that overcrowding results from a constant increase in patient volumes and longer stays in the ER (Boyle et al. 1992; Breton and Camirand 1995; Groupe de travail sur l'analyse de la situation dans les urgences 1999; CCNU 2008). The use of emergency rooms by patients with less serious conditions strains the human resources and technologies of both the emergency department and the hospital (Pineault et al. 1989). In Quebec, the average ER stay reached 16 hours in 2008 (CCNU 2008). Annual mean occupation rates for stretchers were at $110 \%$, with yearly peaks as high as $130 \%$ in recent years. Thus, overcrowding can be defined as a situation where the demand for emergency services exceeds the ability to provide care in a reasonable amount of time (CAEPNENA 2001).

Quebec has endured recurrent emergency room crises for nearly 40 years and yet, despite significant investments, still has not managed to resolve these seemingly intractable problems. Could it be that the real, fundamental problem has not been touched? Could it be that corrective measures have aimed at the wrong target?

\section{Our Approach}

Emergency room overcrowding is a challenge to health systems in many parts of the world. There are a number of strong review articles on the various factors involved. Approaching the problem from a systemic perspective, this paper presents instead our views and analysis of the historical context and of the potential solutions to the current situation in Quebec. The paper is organized in the following way. First, we review the history of the healthcare system over the past 40 years, identifying the major orientations that have led to problematic situations in ERs today. We then look at the main solutions that have been tried over time to correct these problems. Finally, we discuss the main challenges that, from our point of view, must be addressed if we are to prevent these problems from constantly recurring. We believe that the Quebec experience can be useful to other provinces that have more recently been faced with such problems.

Our approach is adapted from that of Springate-Baginski and Soussan (2001). 
It is based largely on a review of policy documents, related papers and grey literature and on verification of facts with key informants who have in-depth knowledge of health policies and emergency rooms. The reconstruction of the history was validated by independent analysts and by a workshop with decision-makers, clinicians and researchers interested in the issue of emergency room access and use (Roberge 2008).

\section{The Hospital's Key Role in the Healthcare System}

Several policy decisions taken since the end of the 1950s have placed the hospital at the heart of the Canadian healthcare system and have made the ER the main entry point into the system. This predominant role arises out of the federal government's decision to adopt a policy of incremental public funding of healthcare that began with hospitals (Desrosiers 1999). Canada's Hospital Insurance and Diagnostic Services Act of 1957 provided free care in hospitals and outpatient clinics, including complementary laboratory and radiology services, but this free access did not extend to private medical clinics. This led to a public perception of hospitals as a first recourse, because they were the only place where services were "free" (Desrosiers 1999).

In Quebec, this perception was reinforced by the decision to develop hospitalbased outpatient services, to the detriment of services provided outside hospitals. Notably, one of the dispositions of Quebec's 1971 framework legislation on health and social services found in no other province or territory in Canada stipulates that hospitals must recruit general practitioners and place them in charge of emergency services (Desrosiers 1999). With this legislation, a front-line emergency service was created in hospitals, and general practitioners no longer had any incentive to develop an extended and integrated network of services outside them, especially since, at that time, massive investments were being made in facilities and equipment for hospitals' outpatient services (Desrosiers and Gaumer 1987).

Following the establishment of hospital insurance, the resource planning undertaken in Quebec significantly modified the missions of acute care hospitals. These changes had a definite impact on the internal organization of these hospitals and of their emergency services. As the system underwent a process of deinstitutionalizing psychiatric patients, hospitals found themselves, in the early 1970s, entrusted with the responsibility of caring for mental health problems. A new clientele, coming out of the "asylums," would henceforth turn to the emergency rooms. Then, in 1976, the Ministry of Health and Social Services (MSSS) required all hospitals with 200 or more beds to reserve $10 \%$ of their beds for long-term care. Very soon thereafter, in most hospitals, the proportion of long-term beds greatly surpassed this initial standard. Faced with this situation, hospitals were given priority for admissions into the long-term care network. Thus, the hospitals, via their emergency rooms, rapidly became the point of entry for the elderly into this network (CSSSMM 1977). In addi- 
tion, hospitals became an important safety net for the elderly population seeking home care, because the government invested very little in such services at that time (Pineault et al. 1989). Finally, the hospital also gradually became the preferred location for endof-life care, whereas before, most people died in their homes.

Further, when hospitals became public establishments, they received global budgets that were partly based on their past activities. This approach to budget-setting, which is also predominant elsewhere in Canada, although with some variations, is one of the factors that has most debilitated the healthcare network (Ouellette 2007). Because it is not directly linked to either the quantity or the quality of services provided, it does not encourage efficiency, nor does it provide any productivity incentives. Hospitals budgets remain the same regardless of their activities. Thus, hospital administrations adopted management strategies that had an impact on the availability of acute care beds and on the capacity to admit patients via the ER. For example, for the past several years, hospitals have elected to close beds temporarily at the end of the fiscal year to avoid incurring a budget deficit.

Finally, in recent decades, many factors have affected the availability of beds. In the overall movement of re-thinking massive investments in hospital-based services (Evans et al. 1994; Angus et al. 1995), and following upon the Rochon Commission's recommendations (1988), hospitals in the early 1990s had to make the shift towards ambulatory care. In this same period, under pressure from the need to balance budgets, the federal and provincial governments undertook policies of reducing expenses that resulted in massive cutbacks to hospitals. These severe cuts led to closures not only of beds, but of entire hospitals, and drastic reductions in qualified medical and nursing staff ("La Prochaine réforme" 2000). The result was

Hospitals' budgets remain the same regardless of their activities. Thus, hospital administrations adopted management strategies that had an impact on the availability of acute care beds and on the capacity to admit patients via the ER. a reduction in the availability of short-term care beds, a movement that was, in fact, observed throughout Canada and all the OECD countries (OECD 2007). Still, it is difficult to draw conclusions about the adequacy of resources in terms of beds. The existing standards for these resources are neither shared nor stable, particularly because of

the rapidity and scope of changes in diagnostic and therapeutic procedures and in the locations of service delivery to patients (Christensen et al. 2000; Institute of Medicine 2001; Contandriopoulos et al. 2005). Nevertheless, hospital administrators have noted an insufficiency of beds (Contandriopoulos et al. 2005) and consider the lack of beds 
to be a factor in ER overcrowding (Rowe et al. 2006). The appearance of overflow units in many ERs is possibly symptomatic of a reduced capacity in hospitals to admit patients ("La Prochaine réforme" 2000).

\section{A Weak Primary Healthcare Network Poorly Coordinated with the Rest of the System}

Various decisions taken over the years regarding the organization and funding of primary healthcare services had important consequences for ER utilization. In Quebec, the 1971 health and social services legislative framework was based on a vision of primary care services anchored in the community that would integrate the health and social services sectors. This idea found its application in the creation of local health and social services centres (CLSCs). Physicians expressed considerable opposition to the CLSCs and to salaried remuneration (Lesemann 1981). This opposition led to the development of a large network of private clinics (Levesque and Bergeron 2003), which has become the prevalent model for primary care services, as in the rest of Canada (Hutchison et al. 2001). These two networks, public and private, have evolved in parallel; today there are around 800 private clinics and 147 CLSCs (Levesque et al. 2007). The CLSCs were implemented in successive waves, without their mission ever being clearly defined. Not only have the CLSCs not become the main door into the system, as envisioned, but in fact they remain poorly integrated into the rest of the system, particularly in urban areas, and they are considered to be rather unproductive (Bozzini 1988; Desrosiers 1982a,b; Lesemann 1981; Pineault et al. 2008).

Until quite recently, healthcare reforms paid little attention to the network of private clinics. Even in the shift towards ambulatory care in the 1990s, savings generated in hospitals were only partially redirected towards the primary care network, and this network has not been reorganized (Clair 2000). In addition, the Canada Health Act of 1984 maintained the obligation for hospitals to provide diagnostic services at no charge, without extending this free access to the same services provided in medical clinics. Thus, to some extent, the law contributed to the rationing of resources in the primary care network (Lamarche et al. 2007). In fact, physician remuneration constituted the primary source of funding for medical clinics. For the most part, these clinics were formed as small entities supported by minimal diagnostic, therapeutic and informational infrastructures, which rendered the primary network that much more precarious (Hamel et al. 2007). Moreover, the absence of any financial or clinical integration means that the medical clinics remain poorly coordinated with the other components of the healthcare network, such that physicians and administrators see little advantage in working together (Lamarche et al. 2007; Levesque et al. 2007). Finally, the primary healthcare network that has sprung up is mainly focused on drop-in services 
The Continuing Saga of Emergency Room Overcrowding: Are We Aiming at the Right Target?

to the detriment of any practice oriented towards the management of chronic illnesses (Hamel et al. 2007). In fact, Quebec is the province with the fewest family physicians per capita. It is also among the provinces with the poorest accessibility to primary care services (Lamarche et al. 2007). Recent studies from the patients' perspective show that patients who experience poorer accessibility to and continuity of primary care are more likely to use the ER (Ionescu-Ittu et al. 2007; Roberge et al. 2007;

It is not surprising that the ER has become the substitute location for primary care, providing access to diagnostic services and to generalist and specialist physicians who have become otherwise difficult to access.

Haggerty et al. 2007).

All in all, the role assigned to hospitals, and the decisions taken regarding the organization and funding of the hospital network, added to the parallel development of a weak primary healthcare network. Together, these factors have led to the problems now being experienced in ERs. It is not surprising that the ER has become the substitute location for primary care, providing access to diagnostic services and to generalist and specialist physicians who have become otherwise difficult to access. Nor is it surprising that the ER has become a substitute for hospitalization, to the point where many hospitals have set up short-stay units in proximity to the emergency room.

\section{Symptomatic Treatment for Emergency Room Problems}

For more than 40 years, efforts have been made to resolve the ER crisis by working either upstream or downstream, or on emergency room functioning. The nature of the solutions that have been tried is particularly consistent with the role assigned to hospitals over the years, to the detriment of primary care services. The solutions have also been greatly influenced by the results of an empirical cross-sectional study carried out in the mid-1980s (Spitzer and Sicotte 1985), which concluded that ER overcrowding was essentially due to the excessively long stays of patients on stretchers, particularly those waiting to be admitted. As mentioned, later studies revealed the extent to which steady growth in patient volume contributes to the congestion. More recently, the measures implemented have generally tried to correct only one aspect of the problem, i.e., stretcher patients, while little attention has been paid to the utilization of emergency services by ambulatory patients.

The MSSS has thus established a system for monitoring ER activities that is based almost exclusively on indicators related to stretcher patients and has developed standards for their length of stay. Inexplicably, these far exceed standards promoted 
elsewhere in Canada and in the world (Vadeboncoeur et al. 1999). For example, one standard relates to the proportion of patients staying longer than 48 hours in the ER, which should not exceed $4 \%$.

Among the classic solutions implemented in the past 30 years was the establishment of new places for the elderly in long-term care facilities to free acute care hospital beds and stretchers occupied by patients waiting for admission to long-term care. Another was the occasional injection of funds into hospitals to re-open beds that had been closed to balance budgets. Such measures had only a moderate impact on ER overcrowding (Boyle et al. 1992).

Government authorities also adopted performance improvement measures that were sometimes motivating or, at other times, coercive. For example, the Tactical Intervention Group implemented in the early 1990s - a sort of "emergency room police" - had the power to recommend sanctions (e.g., budget cuts) against hospitals that did not manage to respect the standard of a maximum 48-hour stay (Groupe tactique d'intervention 1991). Other approaches included the organization of public forums on the issue (MSSS 1999) and, at the beginning of this decade, the implementation of legislative and incentive measures aimed at constraining the loss of qualified manpower in the ER ("Pour pallier la crise" 2007; "Infirmières" 2007). All these measures constituted symptomatic treatments in times of crisis. They helped to defuse the crises of the moment, but without actually resolving the fundamental problems of emergency rooms conclusively.

Finally, as is well known, emergency rooms have long been the focus of extensive media coverage. To some extent the media attention, and consequently the attention from politicians, probably provided significant leverage for managers and professionals in hospitals and emergency rooms ("La Prochaine réforme" 2000; "Guérir les urgences" 2002). History has shown that media visibility over the years has been a source of pressure on decision-makers, who have had to react to dramatic revelations and horror stories (“Une réforme urgente” 2000).

\section{Conclusions}

A historical overview of the broad orientations of the healthcare system reveals that the recurrent ER crisis is symptomatic of a much deeper problem. It results from directions set many years ago that gave hospitals a predominant role at the expense of primary care, while leaving both networks to evolve in parallel. It is also a reflection of Quebec's healthcare system performance, which falls within the average in Canada but is far from being among the best in the world (Lamarche et al. 2007). One of the system's main weaknesses is in the organization of primary care, which is strongly focused on acute health problems, to the neglect of long-term management of chronic diseases. 
A major component of the solution to ER problems is therefore to be found in strengthening and reorganizing primary care services. It has been amply demonstrated that the most efficient healthcare systems are those in which service provision is based on a well-organized primary care network (Starfield 1998; Macinko et al. 2003; Shi and Starfield 2001). There is, moreover, consensus in Quebec and in Canada around the need to consolidate primary care services (Clair 2000; Kirby 2002; Romanow 2002). On this subject, the recent work of Quebec's Study Group on Health Care System Funding (Castonguay et al. 2008) recommended developing primary care services in organizations that will assume responsibility for health status, access and coordination of services for individuals and communities, in ways that extend beyond their contact with the healthcare system and the provision of walk-in services. Developing such organizations involves group practice, multidisciplinary teamwork, technologies for diagnosis and treatment that support the responsibilities assumed, and mechanisms to coordinate services. It also requires proper funding of primary care services and physician remuneration systems based on scope of responsibilities (e.g., capitation) (Lamarche et al. 2007).

Another fundamental issue in resolving the ER situation is the need to reinforce integration among the levels of service. Making health organizations' funding interdependent and tied to productivity will motivate them to define one another's roles and promote integration among the different network partners. The experience of Kaiser Permanente and the Veterans Administration in the United States are illustrative examples of systems that combine these characteristics. The results are striking: thanks to a payment-for-performance system, and by shifting resources from the hospital to the ambulatory care level, these systems have achieved better health outcomes with lower hospital and ER utilization (Feachem et al. 2002; Armstrong et al. 2006).

Finally, strengthening primary care and promoting the integration of service levels requires changing the Canada Health Act, which in fact limits coverage of services to those supplied by hospitals and physicians. Such a modification would broaden coverage to include services provided by primary care organizations, and the federal government's contribution would not be linked with service location (Lamarche et al. 2007).

If we do not deal with the historical residues that are paralyzing our healthcare system, we will have to keep managing increasingly severe crises in our emergency rooms. We know that symptomatic remedies provide only temporary relief. The treatment required is more complex and long-term.

Correspondence may be directed to: Danièle Roberge, Centre de recherche, Hôpital Charles Le Moyne, 3120 Boulevard Taschereau, Greenfield Park, QC J4V 2H1; tel: 450-466-5000; ext. 3017, e-mail: daniele.roberge@usherbrooke.ca. 


\section{REFERENCES}

Angus, A.E., A. Ludwig, J.E. Cloutier and T. Albert. 1995. Sustainable Health Care for Canada. Synthesis Report. Ottawa/Kingston: Queen's University of Ottawa Economic Projects.

Armstrong, B., O. Levesque, J.B. Perlin, C. Rick, G. Schectman and P.M. Zalucki. 2006."Reinventing Veterans Health Administration: Focus on Primary Care." Healthcare Quarterly 2: 80-85.

Boyle, P., R. Pineault and D. Roberge. 1992. "Assessing Quebec's Multi-Component Program to Reduce Emergency Room Overcrowding." Canadian Public Policy 18(2): 189-202.

Bozzini, L. 1988. "Local Community Services Centres (CLSCs) in Quebec: Description, Evaluation, Perspectives." Journal of Public Health Policy 9(4): 346-75.

Breton, M. and F. Camirand. 1995. État de situation dans les salles d'urgences 1991-1995. Quebec: Ministry of Health and Social Services, Government of Quebec.

Canadian Association of Emergency Physicians and National Emergency Nurses Affiliation (CAEPNENA). 2001."Joint Position Statement on Emergency Department Overcrowding." Canadian Journal of Emergency Medecine 3(2): 82-84.

Castonguay, C., J. Marcotte and M. Venne. 2008. En avoir pour notre argent. Rapport du Groupe de travail sur le financement du système de santé. Quebec: Government of Quebec.

Christensen, C.M., R. Bohmer and J. Kenagy. 2000 (September-October). "Will Disruptive Innovations Cure Health Care?" Harvard Business Review 78(5): 102-11.

Clair, M. 2000. Les Solutions émergentes : rapport et recommandations. Quebec: Commission d'étude sur les services de santé et les services sociaux.

Comité de coordination nationale des urgences (CCNU). 2008 (March). Données évolutives régionales des taux d'occupation des civières et des durées de séjour dans les services d'urgence au Québec, 1998-2008. Unpublished work.

Conseil de la santé et des services sociaux de Montréal métropolitain (CSSSMM). 1977 (January). Rapport de l'étude sur les politiques d'admission des malades dans 25 centres hospitaliers de courte durée opérant un service d'urgence de la région de Montréal. Montreal: Author.

Contandriopoulos, D., A.-P. Contrandriopoulos, J.-L. Denis and A. Valette. 2005. L'Hôpital en restructuration. Regards croisés sur la France et le Québec. Montreal: Les Presses de l'Université de Montréal.

Desrosiers, G. 1982a (January 30)."Les Centres locaux de services communautaires au Québec." Le Concours médical: 649-53.

Desrosiers, G. 1982b (February 6)."Les Centres locaux de services communautaires au Québec." Le Concours médical: 847-50.

Desrosiers, G. 1999. “Le Système de santé au Québec bilan historique et perspective d'avenir : conférence inaugurale du 51e congrès de l'Institut d'histoire de l'Amérique française, octobre 1998." Revue d'histoire de l'Amérique française 53(1): 3-18.

Desrosiers, G. and B. Gaumer. 1987. L'Occupation d'une partie du champ des soins de première ligne par l'hôpital général : faits, conséquences, alternatives. Rapport présenté à la Commission d'enquête sur les services de santé et les services sociaux. Quebec: Les Publications du Québec.

“Emergency Ward on Lawn Approved." 1987 (June 1). Toronto Star: A7.

"ER Crowding Getting Worse: Hospitals Turning Ambulances Away More Often." 1999

(November 22). Hamilton Spectator: A2. 
"ER Overcrowding Delays Crucial Clot Busters for Heart Attack Patients." 2004 (November 26). Edmonton Journal: A18.

Evans, R., M.L. Barrer and T. Marmor. 1994. Why Are Some People Healthy and Others Not? The Determinants of Health of Populations. New York: Aldine de Guyer.

Feachem, R.G.A., N.K. Sekhri and K.L. White. 2002."Getting More for Their Dollar: A

Comparison of the NHS with California's Kaiser Permanente." British Medical Journal 324: 135-43.

Groupe de travail sur l'analyse de la situation dans les urgences. 1999. Plan d'action : la situation dans les urgences en 1999. Un défi majeur pour le réseau. Quebec: Ministry of Health and Social Services.

Groupe tactique d'intervention. 1991. Rapport de la première année d'activité. Quebec: Ministry of Health and Social Services.

“Guérir les urgences. Québec : à quand la décongestion ?” 2002 (September 15). La Presse: A8.

Haggerty, J.L., D. Roberge, R. Pineault, D. Larouche and N. Touati. 2007."Features of Primary

Healthcare Clinics Associated with Patients' Utilization of Emergency Rooms: Urban-Rural

Differences." Healthcare Policy 3(2): 72-85.

Hamel, M., R. Pineault, J.F. Levesque, D. Roberge, A. Lozier-Sergerie, A. Prud'homme and B.

Simard. 2007. L'Organisation des services de santé de première ligne : portrait des services médicaux de première ligne à Montréal et en Montérégie. Rapport et résumé. Montreal: Institut national de santé publique du Québec, Agence de la santé et des services sociaux de Montréal and the Research Centre of Charles LeMoyne Hospital.

Hutchison, B., J. Abelson and J. Lavis. 2001 (May-June). “Primary Care in Canada: So Much Innovation, So Little Change." Health Affairs 20(3): 116-31.

"Infirmières : Couillard maintient les primes. Une mesure temporaire en attendant une solution permanente." 2007 (November 13). Le Devoir: A1.

Institute of Medicine. 2001. Crossing the Quality Chasm: A New Health System for the 21st Century. Washington, DC: National Academy Press.

Ionescu-Ittu, R., J. McCusker, A. Ciampi, A.-M. Vadeboncoeur, D. Roberge, D. Larouche, J. Verdon and R. Pineault. 2007. "Continuity of Primary Care and Emergency Department Utilization among Elderly People." Canadian Medical Association Journal 177(11): 1362-68.

Kirby, M.J.L. 2002. The Health of Canadians - The Federal Role. Final Report. Volume Six:

Recommendations for Reform. Ottawa: The Standing Senate Committee on Social Affairs, Science and Technology.

Lamarche, P.A., R. Pineault and Y. Brunelle. 2007 (October 31). Modes d'organisation des services prometteurs pour le Québec. Rapport déposé au Groupe de travail sur le financement des services de santé.

"La Prochaine réforme de la santé doit inciter à la productivité : notre système actuel vise principalement à rationner les ressources au lieu d'être bâti pour viser l'amélioration des services et la satisfaction des 'clients"' 2000 (November 3). Le Devoir: A9.

Lesemann, F. 1981. Du pain et des services : la réforme de la santé et des services sociaux au Québec (pp. 159-63, 193-95). Montreal: Éditions Coopératives Albert Saint-Martin.

Levesque, J.F. and P. Bergeron. 2003. "Quebec's Health Care System: Origins, Organization and Future." In C.P. Shah, ed., Public Health and Preventive Medicine in Canada, 5th ed. (pp. 517-29). Toronto: W.B. Saunders Canada. 
Levesque, J.F., D. Roberge and R. Pineault. 2007."La Première ligne de soins : un témoin distant des réformes institutionnelles et hospitalières au Québec?” In M.J. Fleury, M. Tremblay, H. Nguyen and L. Bordeleau, eds., Le Système sociosanitaire au Québec: gouvernance, régulation et participation (pp. 63-78). Montreal: Gaëtan Morin éditeur, Chenelière Éducation.

Macinko, J., B. Starfield and L. Shi. 2003."The Contribution of Primary Care Systems to Health Outcomes within Organization for Economic Co-operation and Development (OECD) Countries, 1970-1998." Health Services Research 38(3): 831-65.

Ministère de la santé et des services sociaux (MSSS). 1999. Relever ensemble le défi des urgences. Plan d'action issu du forum sur la situation des urgences tenu à Montréal les 4 et 5 octobre. Quebec: Author.

Ministère des affaires sociales du Québec (MASQ). 1974. Rapport du comité « Système de services d'urgences ». Quebec: Author.

Organization for Economic Co-operation and Development (OECD). 2007. Health at a Glance: OECD Indicators. Copenhagen: Author.

Ouellette, P. 2007. Efficience et budgétisation des hôpitaux et autres institutions de santé au Québec. Rapport de recherche remis au Groupe de travail sur le financement du système de santé. Montreal: University of Montreal.

Pineault, R., J.-F. Levesque, M. Breton, M. Hamel and D. Roberge. 2008. "Réalisations et potentiel des organisations publiques et privées de première ligne dans deux régions du Québec." In $\mathrm{F}$. Béland, A.-P. Contandriopoulos, A. Quesnel-Vallée and L. Robert, eds., Le Privé dans la santé : un débat sans fin? Montreal: University of Montreal.

Pineault, R., D. Roberge, P. Boyle, Y. Pelchat and C. Sicotte. 1989. Évaluation de l'efficacité et de l'efficience des mesures gouvernementales visant à réduire l'engorgement des salles d'urgence. Rapport final. No. R89-04. Montreal: Groupe de recherche interdisciplinaire en santé, University of Montreal.

"Pour pallier la crise attendue cet été dans les hôpitaux. Une prime aux infirmières des salles d'urgence." 2007 (June 10). La Presse: A10.

Roberge, D. 2008 (April 17). "La Petite histoire des urgences au Québec de 1960 à ce jour." Allocution présentée dans le cadre du colloque « Pour en finir avec les urgences », Montreal.

Roberge, D., D. Larouche, R. Pineault, J.-F. Levesque, M. Hamel and B. Simard. 2007. "L'Urgence des hôpitaux : un filet de sécurité pour la première ligne ?” Première ligne 21(3): 16-23.

Rochon, J. 1988. Rapport de la Commission d'enquête sur les services de santé et les services sociaux. Quebec: Les Publications du Québec.

Romanow, R.J. 2002. Building on Values: The Future of Health Care in Canada - Final Report. Saskatoon: Commission on the Future of Health Care in Canada.

Rowe, B.H., K. Bond, M.B. Ospina, S. Blitz, M. Schull, G. Innes, M. Afilalo, M. Bullard, S.G. Campbell, G. Curry, B. Holroyd, P. Toon and D. Sinclair. 2006. Emergency Department Overcrowding in Canada: What Are the Issues and What Can Be Done? Technology Overview No. 21. Ottawa: Canadian Agency for Drugs and Technologies in Health.

Schoen, C., R. Osborn, P.T. Huynh, M. Doty, K. Davis, K. Zapert and J. Peugh. 2004. "Primary Care and Health System Performance: Adults' Experiences in Five Countries." Health Affairs Web Exclusive: W4-487-W4-503. Retrieved January 7, 2010. <http://content.healthaffairs.org/cgi/ reprint/hlthaff.w4.487v1>. 
The Continuing Saga of Emergency Room Overcrowding: Are We Aiming at the Right Target?

Schoen, C., R. Osborn, S. How, M. Doty and J. Peugh. 2008. "In Chronic Condition: Experiences of Patients with Complex Health Care Needs, in Eight Countries, 2008." Health Affairs Web Exclusive: W1-W16.

Schoen, C., R. Osborn, P.T. Huynh, M. Doty, K. Zapert, J. Peugh and K. Davis. 2005. “Taking the Pulse of Health Care Systems: Experiences of Patients with Health Problems in Six Countries." Health Affairs Web Exclusive: W5-509-W5-525. Retrieved January 7, 2010. <http://content. healthaffairs.org/cgi/reprint/hlthaff.w5.509v3>.

Shi, L. and B. Starfield. 2001."The Effect of Primary Care Physician Supply and Income Inequality on Mortality among Blacks and Whites in US Metropolitan Areas." American Journal of Public Health 91(8): 1246-50.

Spitzer, W.O. and C. Sicotte. 1985. Analyse statistique, opérationnelle et clinique du phénomène de l'engorgement des salles d'urgence des centres hopitaliers de courte durée de la région montréalaise (06A). Montreal: McGill University.

Springate-Baginski, O. and J. Soussan. 2001. A Methodology for Policy Process Analysis: LivelihoodPolicy Relationships in South Asia. London: UK Department for International Development.

Starfield, B. 1998. Primary Care: Balancing Health Needs, Services and Technology, rev. ed. London: Oxford University Press.

Steinmetz, N. and J.R. Hoey. 1978. "Hospital Emergency Room Utilisation in Montréal Before and After Medicare. The Quebec Experience." Medical Care 16(2): 133-39.

"Une réforme urgente et nécessaire." 2000 (June 3). La Presse: B2.

Vadeboncoeur, A., P. Beaudet, K. Pecko and D. Somerville. 1999. Projet urgence 2000 : de paratonnerre à plaque tournante. Quebec: Ministry of Health and Social Services. 